[12] Andrushchenko, V., Divins'ka, N., Korol'ov, B. (2008). Osobystisno oriyentovani tekhnolohiyi navchannya i vykhovannya u vyshchykh navchal'nykh zakladakh. Kiev: Pedahohichna dumka, 256.

[13] Pometun, O. I. (2004). Dyskusiya ukrayins'kykh pedahohiv navkolo pytan' zaprovadzhennya kompetentnisnoho pidkhodu v ukrayins'kiy osviti. Kompetentnisnyy pidkhid u suchasniy osviti: svitovyy dosvid ta ukrayins'ki perspektyvy. Kiev: «K.I.S.», 112.

[14] Panfilova, A. P. (2012). Razvitie issledovatel'skih kompetentnostei magistrantov pri samostoyatel'noi rabote s ispol'zovaniem skyeffoldinga. SaintPeterburg.: Izd. RGPU im. A. I. Gercena, 20-25.

\title{
DEVELOPMENT OF A MODEL OF PROFESSIONAL READINESS FOR FUTURE PILOTS STUDYING AT HIGHER EDUCATION MILITARY INSTITUTES (HEMI)
}

\author{
Roman Nevzorov \\ Department of Flight Tactics and Operation \\ Ivan Kozhedub Kharkiv University of Air Force \\ 77/79 Sumska str., Kharkiv, Ukraine, 61023 \\ roman.nevzorov@list.ru
}

\begin{abstract}
The research seems to be important because Ukraine's integration into international security and European educational systems provide for a high level of professional competence of Ukrainian Armed Forces officers (Ukraine AF), which is considered to be mandatory for assigned task execution, military personnel's coordination in peacekeeping operations and joint military exercises with different countries, as well as for training, experience exchange, and competitiveness. The purpose of the research: The purpose of the article is to develop a model of best practice for future pilots in simulators. Methods of the research: The main method of the research is analysis of literature and documents regulating flight operations, in order to study issues and theoretical and methodological principles of the research and combat flight modeling in simulators to determine the nature and specifics of pilots' activity at different stages of combat flights. Results of the research: The article describes a model of professional practice for future pilots, which includes components of their readiness for combat missions. The practical significance: The model is aimed at teachers' adaptation to new conditions of training of future pilots at HEMIs and at improvement of simulator training.
\end{abstract}

Keywords: pilots' professional readiness, combat flight simulation, simulator, simulation practice.

\section{Introduction}

Practical measures regarding Euro-Atlantic integration of Ukraine require modern pedagogical technologies, rethinking of concepts of training of military specialists of Ukrainian Air Force (Ukraine AF).

Ukrainian Air Force was established in 2004 by combining Air and Air Defense Forces of the country. This maneuverable type of forces is designed to protect airspace, destroy enemies' facilities from air, to provide air support for own troops, to land and air born invasion and air transportation of troops and materials, and aerial reconnaissance. The following planes are adopted in the Air Force: MiG-29, Su-27, Su-25, Su-24M, Su-24MR, Il-76MD, An-26, An-24, L-39, anti-aircraft missile systems S-300, and "Buck" in various versions.

In current conditions of anti-terrorist operation (ATO) and due to the Russian aggression, training of military pilots, effective planning of the use of forces in air combats against enemy's attacks and air strikes on objects (force grouping) in response are urgent, so it is believed to be important for pilots to practice their skills, particularly tactical flight tasks in the day and night, live firing and bombing practice. It is important to train pilots to protect against air strikes on key objects and troops. Special attention should be paid to organization and cooperation between the groups and means of the Ukrainian Armed Forces, other military formations and law enforcement. Therefore, the main strategy of pilot training should consist of the study and development of ef- 
fective teaching methods, creation of appropriate teaching conditions, generation of intellectual initiative and enhance of thinking of cadet pilots during their studying.

Air Force is a part of Armed Forces of Ukraine, which in peacetime protects the state border in airspace and defends important state objects from air. Combat crews of fighter aircraft, anti-aircraft missile and radio units provide integrity for over seven thousand kilometers of the state boundaries, control over aircraft flights through the Ukrainian borders with nine countries. Therefore, preparation of high-quality pilots of fighter aircraft of the Air Forces of Ukraine seems to be urgent as ever.

\section{Literature Review}

The image of a modern military pilot, being the essence of professional readiness for battle, is formed during learning at a higher educational military institution through gradual involvement into appropriate practices with special flight simulators, accumulation and interpretation of personal experience. Scientific category "readiness" was studied in researches by psychologists and teachers $[1,2]$.

Scientists [3, 4] and others formulated in their papers theoretical principles of construction and use of aircraft simulators. Scientists [3] gave some definitions and concepts related to professional training. The scientist defined a simulator as a teaching tool psychologically simulating the reality, intended to develop appropriate skills. Researches by [3] also showed that simulators were considered not only to be an effective tool for the development of professionally important qualities of student pilots, but also means of forecasting of military pilots' professional skills in combat missions. But the development of future pilots' professional competence and use of flight simulators is not studied enough. Pedagogical conditions require to be substantiated, it is advisable to develop a model of professional competence and scientific guidance of the effective development of specified competence of future pilots.

European scientists $[5,6]$ emphasized the use of simulators improving the realism of preparation for a flight.

Quality training of pilots can be achieved by changes in teaching and intensive combat training on relevant weapons and military equipment. However the training of pilots and operators of complex systems at operating facilities are expensive and often dangerous. Pilots' skills are considered to be one of the key indicators of their professional readiness. This necessitates development of methods of application of simulation technologies in teaching, and their intensive use at a higher military educational institution (HEMI) and Air Force of Ukraine.

\section{Purpose and research tasks}

The purpose of article consists in the development of the model of the process of formation of professional readiness of future pilots which is implemented in the course of simulation practice.

For achievement of a goal the following tasks have been set:

1. To define pedagogical conditions of formation of readiness for student pilots' readiness for air combat of higher educational institutions.

2. To analyze components of professional readiness of cadets pilots for performance of fighting tasks.

3. To analyze components and components of structure of readiness of future pilots for performance of fighting tasks.

4. To formulate the main maintenance of the model of the process of formation of professional readiness of future pilots, implemented in the course of simulation practice.

\section{Materials and research methods}

To achieve the first purpose, the following methods are applied: analysis of literature and documents regulating flight operations, in order to study issues and definitions of theoretical and methodological principles of the research; specification, induction and deduction of theoretical knowledge; abstraction, classification and systematization of theoretical and experimental data on 
the research; combat flight modeling in simulators to determine the nature and specifics of pilots' activity at different stages of combat flights.

The main method of the research of this problem is the method of the analysis of the references and documents regulating pilots' activity for the study of the purpose of the problem and determination of methodological bases of the research and the method of simulation of combat flights on aviation training means for determination of an entity and specifics of the process of pilots' activity at different stages of combat flight.

\section{Results of the research}

A pilot is a subject of military and professional development, a military expert as a subject of military activity. Pilots' development is caused by innovative learning at HEMI considering specifics of pilots' military training during professional development, they formed complex skills of a unique character and individual style.

A model of the professional readiness of student pilots for combat missions is based on the following components: motivation, orientation, operational, strong-willed, evaluation [7] (Table 1).

Table 1

Components of professional readiness of student pilots for combat missions

\begin{tabular}{|c|c|c|c|c|c|}
\hline Evaluative & Emotional & Volitional & Operation & Orientation & Motivation \\
\hline $\begin{array}{l}\text { evaluation of } \\
\text { own abilities, } \\
\text { claims for } \\
\text { certain results, } \\
\text { ability to assess } \\
\text { the situation, to } \\
\text { think critically }\end{array}$ & $\begin{array}{l}\text { ability to manage } \\
\text { own emotions, } \\
\text { emotional sensi- } \\
\text { tivity in solving } \\
\text { learning tasks }\end{array}$ & $\begin{array}{l}\text { mobilization of } \\
\text { forces in accor- } \\
\text { dance with condi- } \\
\text { tions and knowl- } \\
\text { edge, self-control, } \\
\text { self-suggestion in } \\
\text { achieving the goals }\end{array}$ & $\begin{array}{l}\text { determination based } \\
\text { on experience and } \\
\text { assessment of intended } \\
\text { operating conditions, the } \\
\text { most likely ways to solve } \\
\text { problems or to comply } \\
\text { with requirements (usage } \\
\text { of methods and techniques, } \\
\text { knowledge, skills, abilities, } \\
\text { mental anticipation, analy- } \\
\text { sis, synthesis, comparison, } \\
\text { generalization) }\end{array}$ & $\begin{array}{l}\text { awareness of purposes, } \\
\text { allowing to solve a spe- } \\
\text { cific task, understand- } \\
\text { ing and assessment of } \\
\text { conditions for future } \\
\text { actions, actualization } \\
\text { of past experience } \\
\text { associated with similar } \\
\text { tasks and requirements }\end{array}$ & $\begin{array}{l}\text { understanding their } \\
\text { needs, interests, } \\
\text { societies' and groups' } \\
\text { requirements }\end{array}$ \\
\hline
\end{tabular}

in Table 2.

Basing on the studied approach, we define the structure of future pilots' readiness shown

Let's consider the main values offered by the author of the model.

The pilot's professional competence means professional knowledge, practice, and readiness for combat missions.

The model shows requirements for pilot's' competence as a component of their professional readiness to combat missions, goals, tasks, and methodological approaches.

Professional knowledge and skills in combat missions (performance of different combat flight) are considered to be as a component in future pilots'competence.

The psychological and pedagogical knowledge is determined by curriculum training of pilots at HEMIs. Psycho-pedagogical preparedness consists of knowledge of methodological categories of airmanship, socialization patterns, personal development, goals, and makes the basis for pilot's creative thinking. Ability is a sequence of theoretical knowledge based actions. Some actions can be automated (skills).

Motivational reflective component .A reflexive component characterizes the pilot's knowledge and analysis of own consciousness and activity. This component is implemented through self-understanding and self-appraisal, understanding and evaluation of others.

Motivation and positive attitude to flying activity, desire to do. The pilot's motivation is caused by professional interests, values, ideals. It appears as if throughout his professional life, and in some combat situations, defines his perception of external events and logic behavior during combat missions. 
Table 2

Components and structures of future pilots' readiness for combat missions

\begin{tabular}{|c|c|c|c|}
\hline \multicolumn{4}{|c|}{ Social and educational requirements and standards of professional competence formation pilot } \\
\hline Goal & \multicolumn{3}{|c|}{ To develop pilot's professional competence } \\
\hline \multirow[t]{2}{*}{ Task } & \multicolumn{3}{|c|}{ To create all components in complex, allowing effective professional career of military pilots } \\
\hline & Methodological approaches & \multicolumn{2}{|c|}{ Didactic principles } \\
\hline \multicolumn{4}{|c|}{ Methods of development of future pilots' readiness } \\
\hline \multirow[t]{2}{*}{ Pedagogic conditions } & $\begin{array}{l}\text { To develop professional motivation and pilots' self-education } \\
\text { environment, to select training materials, to pro }\end{array}$ & $\begin{array}{l}\text {, to create information } \\
\text { vide subject-subjective }\end{array}$ & $\begin{array}{l}\text { imulation-educational } \\
\text { teraction }\end{array}$ \\
\hline & Simulation training & Theoretical training & $\begin{array}{l}\text { Psychological and } \\
\text { physical training }\end{array}$ \\
\hline \multirow[t]{2}{*}{ Flight training } & Competence & $\begin{array}{l}\text { Motivational and } \\
\text { reflexive }\end{array}$ & Personal \\
\hline & Professional flight skills and practical activities & Self-appraisal & Abilities \\
\hline Values & $\begin{array}{l}\text { Usage of professional knowledge (abilities, skills) in prac- } \\
\text { tice, in simulation and execution of combat missions }\end{array}$ & Motivation & Creativity \\
\hline Result & Formation of future pilot & ' readiness & \\
\hline
\end{tabular}

A personal component is personal qualities important for combat missions. mization.

The pilot's creativity is expressed in an original solution of combat missions, in their opti-

Thus, our model represents criteria and indicators of student pilots' readiness for combat missions. Each is significant for scientific review on issues of Ukrainian Forces' compliance with the standards and for the author's definition of readiness criteria and indicators.

\section{Discussions of the results}

Professional readiness is an integral education, based on needs and abilities, characterized by social and normative level of public relations transformation into subjects' functions and determines its effectiveness. Pilots' professional readiness to combat tasks is connected with skills to perform various combat flights in simulators.

According to GOST 21036-75, a simulator means a technical device for professional training of a human operator, designed for development and improvement of professional skills required for an object operation, by repeated actions. So, in general, an aircraft simulator is specialized technical means simulating the piloting process in land conditions with a high similarity to a real flight [8].

According to the "Rules for certification of aircraft simulators' a flight training device (FTD)is an aircraft simulator, consisting of instruments, equipment, panels and controls within an open or closed cockpit layout of the aircraft. It includes hardware and software required to simulate conditions of the aircraft on the ground and in the air within the system capabilities modeled in this aircraft simulator, and may not have systems of acceleration simulation and/or visualization.

Scientists [9] defined a simulator as a man-machine system that provides a simulation of operation of certain natural man-machine system. Currently simulators are used with high-performance computers for required calculations and display of the situation on the screen able to track all movements of each training student. Also today various combat simulators are widely used either embedded in a real fighting machine or as separate training center based systems or as transportable units. Finally, there are computer simulators designed for training without real weapons samples or imitating their equipment. These trainers can operate within a single network, allowing for comprehensive training of combat missions. 
Simulators have great learning opportunities. They provide conditions similar to real, and practice of important professional knowledge, skills and abilities. A trainer simulates combat flying close to real conditions. A training simulator provides greater opportunities compared to the plane. The studies have shown that simulators provide a comprehensive approach to flight training, allowing to develop knowledge, skills, abilities, and professionally important qualities. Numerous studies have also proved that development of combat aircraft is practically impossible without a well-founded material base (training center) and methodological support [9].

Bringing training atmosphere to real conditions of combat pilots, simulators ensure compliance with psychological and educational requirements to the development of the pilot's skills and abilities.

The simulator safety is considered to be the main characteristic. Trainers provide even more safety than most systems simulated.

First, its impact on student pilots is reduced. Secondly, simulators allow to teach how to execute difficult and challenging tasks when maximum safety a high professionalism is required. Effective use of trainers prevents shortcomings both technical and methodological, in particular, insufficient definition of the simulator role and place in the modern aviation structure, of unified concepts and definitions on technological and methodological aspects of aviation trainers and their operation; unified classification of their main properties; classification of modern aviation training [10].

Scientists [11] said that trainers performed two functions: first - to provide information similar to that provided by the real system; second - to improve and enhance training and education using special means. A simulator stores, processes and displays information that reflects functional characteristics of the system and impact of external conditions and inputs control actions of cadets [1, 12].

Current capabilities allow for training military pilots in different countries in the most realistic environment and prepare them to participate in possible conflicts with regard to real prospective threats. Therefore, the definition of professionally important qualities of student pilots in scientific and pedagogical literature is related to the analysis of psychological readiness (or preparedness), which also describes personal and subjective qualities (Table 3).

Table 3

A model of development of readiness of student pilots for combat missions

Student's personality

Individual substructures

Knowledge and action

Readiness

Types of simulators

(software simulators, training complexes)

Flight trainers

Virtual simulation environment-simulators
Values, reasons, motives, through which a trainee's attitude to reality is expressed

Professional orientation; professional competence; professionally important qualities; professionally important physiological characteristics

Irradiation, concentration, and automation

Psychological readiness to work in special conditions, professional competence (level of general, professional and occupational knowledge and skills)

Functional (primary) cockpits, specialized training; procedural - for testing individual transactions and actions of real activity; complex - for working full-flight missions; group (combination of complex aircraft simulators) for working out team actions

Full Mission Simulator (FMS) - group simulators; Full Flight Simulator (FFS) - complex simulators with visualization systems; Flight Training Device (FTD) - complex simulators of projection visualization systems; Procedures Flight Training Device (FPTD) - procedural simulators

Virtual simulation systems used during combat training of soldiers, crews, and units when performing common tasks

So, the development of new knowledge includes three phases: irradiation, concentration, and automation. Classification of preparedness to simulation is associated with the student's func- 
tional state, subjective psychological characteristics, personal characteristics, practice in flight simulators, activity, pedagogical influence.

Depending on solved tasks, simulators are divided into different types [9].

Functional (primary) cockpits are connected with models of an information display and control panel. They deepen the students' knowledge of aerodynamics and aircraft, drill the pilot's skills during an aircraft operation. The primary aircraft simulators are simple, often made locally by the military institution. Models and stands can be considered as functional simulators.

Specialized simulators are designed to prepare students for certain specific activities, for the development of certain psychological qualities, for drilling piloting skills in specific cases in the dynamics of flight.

Procedural - for working individual operations and actions of real activity.

Complex - for working full-flight missions.

Group (combined complex aircraft simulators) for working crew actions in aviation.

Simulators can be classified by the type of tasks, depending on actions, by qualities, based on the use of assets.

All existing aviation simulators can be divided into two main classes: software simulators; training complexes.

An avian simulator is a flight simulator in any aircraft. They significantly differ in purpose: from mechanic and electronic devices with an instrument panel and front part of the fuselage, designed for training of pilots, to computer games.

Many software simulators are characterized by low reality because they do not allow to use all the senses and used for game purposes at PCs [13].

An integrated simulator is the best technical trainer to prepare flight crews and an effective means to support pilots' skills. An integrated simulator recreates a cockpit interior and allows testing all modes of the aircraft operation. High quality simulators have a complete set of tools that provide an adequate performance in all channels of student's perception.

Flight Procedure Training Devices (FPTD) are designed for procedure working and flight training. Panels, instruments and controls are generally simulated using touch monitors. For convenience, individual panels and controls can be presented as full-size models.

A complex flight simulator (CFL) is kinematics-based. This is the highest level of training. A simulator cockpit is manufactured as a full-size cockpit. Complex simulators are equipped with advanced visualization systems.

Group simulators (Full Mission Simulator - FMS) are designed for practice of a group combat. They are combined into a single network with an HLA interface, which allows to connect various simulators - aircraft, tanks, artillery, and other.

According to USD OD classification, environment-based simulators are divided into real, virtual, and hybrid designs.

Real environment simulation means servicemen working out combat tasks in training. Real environment is modeled by simulators in permanent disposition, at training centers, combined JRTC training center.

Virtual environment simulation is man-operated simulators within an artificial environment. It is created by virtual simulation systems used for combat training of soldiers and crews performing common tasks. Currently these simulation systems are implemented as simulators able to reproduce real operation of equipment. Computers or image generators are used for interaction of servicemen and simulators in an artificial environment. In US Air Force, virtual simulation systems are represented by aviation trainers and simulators for working out joint military operations, for example, distributed computer systems for training of pilots for combat missions.

Constructive environment simulation represents war games and models based on rules, algorithms, and mathematical methods. Constructive simulation systems, forming the environment, are computer-controlled, designed to train the Air Force staff. A constructive simulation system, called "Joint simulation system" JSIMS run by USAD OD, should lower costs for preparation for training through the automatic scenario generation, modeling of enemy's force and environment. 
For training of basic management personnel, an updated version of interactive game simulation system JANUS is to be used.

A hybrid simulation environment is interactive combinations of real, virtual or constructive simulation systems, designed to ensure interoperability of military personnel during combat training. Modern technologies allow to link three environments (real, virtual, and constructive), forming a hybrid environment and providing the personnel with a possibility to attend the training without physical presence. These and other similar technologies hold the key positions during training of combined forces command in solving common problems at all operation levels. The major components of the hybrid simulation environment are: synthetic theater of war - STOW; computer-simulated semi-automated forces - ONESAF; overall technical structure, distributed interactive simulation technology - DIS [14].

Scientists [15] brought a different classification of aircraft simulators. He divided them into piloting, navigation, and complex simulators which include: trainers, providing land training of crews and control over actions while performing complex tasks in the aircraft at all flight stages and in emergency situations; electronic, radio devices, systems and their simulators, digital and analog computers and devices, electricity sources and converters [15].

Considering importance of simulator training in development of professional skills, safety during training of combat missions, comprehensive and systematic approaches are recommended. So aviation simulators can be divided into three types:

- procedural;

- module;

- complex.

Procedural simulators help students to learn to partly perform practical actions for certain procedures, combat flights without an instructor, applying the knowledge from theoretical knowledge [16]. Procedural trainers develop skills only for certain combat missions and can be used at colleges for initial training.

Procedural simulators have a low similarity factor compared to other simulators and perform tasks related to obtaining skills of combat mission procedures. Modular trainers have a high similarity factor, perform almost all problems associated with practical skills of combat missions. Complex simulators have the highest similarity factor, perform all tasks associated with practical skills of combat missions [17].

Procedural simulators require developed exercises for individual elements and technological procedures to improve skills. Thus, one student can work in a simulator over a specific task. This simulator can operate in training and knowledge control.

Instructors for modular simulators should be experienced professionals trained at special courses at institutions.

Upon review of the main types and general characteristics of simulators and tasks to be performed, let's make conclusions on the optimal use of simulators.

The disadvantage of modular simulators is that they develop only important professional qualities of an individual not a group.

Complex simulators allow practical training of pilots and groups both. Complex simulators have a high similarity factor and should be installed at colleges where their operation is profitable. Various exercises should be developed for complex simulators, the same as for module ones, but with the flight plan, covering the entire air flight area [12]. A complex simulator is characterized by group actions with interaction. A complex simulator is the final element of pilot's training, with the highest similarity to actual combat operations. Pilots train skills to analyze situation in complex simulators, learn how to predict their development.

Thus, simulators of all types (procedural, modular, and complex) are mandatory in practical training of pilots, since each type of simulators teaches specific skills, helping to acquire knowledge (Makarov, 2005).

The described systems are developed considering optimization of cost/effectiveness ratio and based on the IBM-oriented software and hardware technology - compatible computers, provid- 
ing high reliability and easy operability. In general (except for complex simulators with a non-fixed cockpit), these systems are compact, portable, consume normal household electricity power and, except a conditioned room, do not require any special conditions [3].

So, simulators are characterized by good training opportunities. They create training environment similar to real and develop professional skills. Working in the simulator can be pre-planned, because it is not affected by weather conditions and it does not need to perform any other tasks.

Modern semi natural military simulators typically include:

- simulators of working places (cockpits, military units) are equipped with controls, display and other devices, similar to real samples of weapons and military equipment;

- a system of sensors, analog-to-digital and digital-to-analog converters;

- local network connecting individual armament trainers with unit trainers;

- software and hardware;

- dynamic platforms;

- working place of a chief who provides the training process and controls the students' actions;

- communications of the chief with the students;

- power supply systems.

Analysis of structural schemes and principles of the most common simulators indicates that they are characterized by the following features:

- different elements in the simulator structure;

- complexity of the structure of relationships between the simulator elements; hierarchical structure;

- unified purpose to be achieved with all elements of the simulator;

- variety of ways to control (central, autonomous, mixed).

These signs indicate that modern semi natural computerized simulators belong to the class of complex organizational systems [18]. This entails to apply systematic research methods.

All major components of the simulator as a means of flight training can be combined into two groups: general systems and specific systems. Thus specific systems can have significant differences for different professional activities, and general systems can be the same for any type of professional activities [8].

Scientists [8] offered the following perspective structure of land training devices:

- complex flight simulator is a technical tool providing full-scale simulation of working places of pilots, flight management group, zone management group, officers providing interaction during simulated combat flight under the supervision of the commander, who manages, monitors, and evaluates students;

- specialized flight simulator is a technical tool providing full-scale simulation of a pilot's workplace connected with the instructor's workplace who manages, monitors, and evaluates students;

- procedural flight simulator (multifunctional)is a technical tool providing a simplified simulation of a pilot's workplace connected with the instructor's workplace, who controls pilot's readiness to flights and provides pre- and post-flight analysis.

The widespread use of functional, procedural, complex simulators at the flight training improves practical skills of pilots to work with control tools. Check of practical skills in simulators allows to quickly assess the level of learning and to respond to insufficient theoretical preparedness [1].

By the terms of use, trainers can be classified as follows [3]: mini-simulators with control levers; procedural simulators with a display panel; complex simulators with a fixed cabin; complex simulators with a non-fixed cabin. This hierarchy of simulators allows to select a specific system based on the objectives of learning, students' qualification.

There are two types of procedural simulators.

A procedural simulator of type II (Flight and Navigation Procedures Trainer - Type II/FNPT II) is a stationary flight simulator, which includes a cockpit model to simulate the aircraft operation, with or without the visualization system.

A procedural simulator of type I (Flight Procedures Trainer and Navigation - Type I/FNPT I) is a stationary flight simulator modeling a cabin interior. 
Simulators of new generation have significant advantages over the previous ones. During the simulation, realistic visual effects can be created against electronic map based real areas. Modern training is an indispensable element in the development of the skills needed in real combat conditions.

Indicators of military training estimation can be divided into several groups (Table 4).

Table 4

Indicators of military training estimation

\begin{tabular}{|c|c|}
\hline Indicator & Characteristic \\
\hline $\begin{array}{l}\text { Indicators of } \\
\text { pilots' pre- } \\
\text { paredness }\end{array}$ & $\begin{array}{l}\text { The degree of execution of tasks of military training programs, firing courses, and flight courses based on: } \\
\text { individual simulators; complex simulators. } \\
\text { Definition of base and current level, pilots' skills (for individual simulators); crew coordination (for complex } \\
\text { simulators); units' military coordination (for tactical simulators). } \\
\text { Opportunity for professional selection (testing) of specialists based on the simulators }\end{array}$ \\
\hline $\begin{array}{l}\text { Indicators } \\
\text { of simulator } \\
\text { adequacy }\end{array}$ & $\begin{array}{l}\text { Completeness of equipment at places for student pilots. } \\
\text { Compliance of the simulator sensory motor field workplaces with a real airplane } \\
\text { Adequacy of a simulation model to a real airplane. } \\
\text { The ability to simulate emergency modes of a real airplane (armament of a real airplane). } \\
\text { The completeness of coverage and combat operations and weapons system functioning of a real aircraft. } \\
\text { Correspondence of training conditions to real conditions: completeness of environment simulation; compliance } \\
\text { of the type and size of the modeled air space with combat training requirements; compliance of micro-climatic, } \\
\text { vibration and noise characteristics of a workplace in the simulator with a real workplace in the real plane. } \\
\text { Possibility to create training conditions throughout all projected conditions of battle (fighting), including: the } \\
\text { scope and nature of the land and air enemy; radio interference, noise in the optical wavelength range, aerosol } \\
\text { obstacles; day time and season; atmospheric phenomena - different intensity fog, rain, snow, wind; tempera- } \\
\text { ture; atmospheric pressure; type of terrain (flat, mountain, desert). } \\
\text { Possibility of two-way battle considering its dynamics and simulated destruction of targets (goals) and samples. } \\
\text { Quality of visualization of situation in the simulator optical devices: information and psychophysical similar- } \\
\text { ity to situation displayed in the simulator optical and aiming devices; dependence of the target angular size } \\
\text { on the distance; target size, shape, and motion parameters; detailing of the near and distant areas of landscape } \\
\text { with plants and local objects and engineering structures; flight simulation and missile burst and machine-gun } \\
\text { fire bursts; optical visibility, simulation of smokescreen of optical devices while firing (missile launches); the } \\
\text { airframe fluctuations during shooting (missile launching) and movement. } \\
\text { The use of digital maps in complex and tactical simulators. } \\
\text { Typical audio and visual effects operation of the aircraft during shooting and movement }\end{array}$ \\
\hline $\begin{array}{l}\text { Indicators of } \\
\text { didactic op- } \\
\text { portunities of } \\
\text { the simulator }\end{array}$ & $\begin{array}{l}\text { Control of information model parameters in the simulator during training according to the purpose and tasks of } \\
\text { combat training. } \\
\text { Objective control of students' actions and automated evaluation of the results of the training tasks. } \\
\text { The degree of automation of the learning process (manual, automated, with hard or flexible programming of } \\
\text { training). } \\
\text { Documentation of the results of training tasks (exercises) during any period of study. } \\
\text { Completeness of the simulator task library }\end{array}$ \\
\hline $\begin{array}{c}\text { Indicators of } \\
\text { reliability }\end{array}$ & $\begin{array}{l}\text { MTBF. } \\
\text { Average life of the simulator. } \\
\text { Continuous operation }\end{array}$ \\
\hline $\begin{array}{l}\text { Indicators } \\
\text { of standard- } \\
\text { ization and } \\
\text { unification }\end{array}$ & $\begin{array}{l}\text { Software and technical compatibility of simulators of the same type. } \\
\text { Ability to work separated in simulators of different purposes, and configuration of a network mode. } \\
\text { The open architecture of the simulator software and hardware }\end{array}$ \\
\hline $\begin{array}{l}\text { Economic and } \\
\text { operational } \\
\text { performance }\end{array}$ & $\begin{array}{l}\text { The cost of the simulator (individual and sample). } \\
\text { The cost of the simulator operation (including energy consumption, maintenance, repair, and number of ser- } \\
\text { vice specialists). } \\
\text { The ability to operate in difficult climatic conditions. } \\
\text { Required space for placement. Requirements for the training class (room). } \\
\text { Ease of maintenance. } \\
\text { Duration of the simulator preparation for employment and training }\end{array}$ \\
\hline
\end{tabular}


Consequently, the modern military simulators market is characterized by various features and price options. In these circumstances, the choice can be done based on comparative assessment of simulators offered by manufacturers, on their performance. This assessment is an objective evidence of an achieved level of trainees, and helps to choose the most appropriate samples among the simulators offered by manufacturers. It is based on multidimensional comparative evaluation [2]. The conclusions by Ukrainian scientists $[19,20]$ should be taken into account since they identified the following structural units of readiness, considering it as a part of the pilot's activity:

- motivation (responsible for the task execution, responsibility sense);

- orientation (knowledge and understanding of characteristics and conditions of its requirements to the individual);

- operational (skills in using methods and techniques, required key competencies);

- volitional (self-control, self-mobilization, ability to manage actions);

- evaluation (self-evaluation of readiness).

\section{Conclusions}

As a result of the researches:

1. Pedagogical conditions of formation of readiness for conducting student pilots' readiness for air combat of higher educational institutions are defined.

Pedagogical conditions of development of HEMI student pilots' readiness for air combat have been determined, namely development of students' professional motivation; students' flight competence; improved efficiency of their academic work using flight simulators.

Development of motivation and activity of future pilots for air combats are proved to be provided by: professional motives; cognitive needs and interests, motivation through learning methods using modern information technologies; modeling of air combats on the land; development of student pilots' readiness; use of aircraft simulators modeling various aviation objects during operation, demonstrating characteristics and conditions of interaction with the environment.

Readiness is associated with professional development of future pilots (external and intra-personal).

One of the best ways to improve training should be the increase in simulator training, learning opportunities by improved quality of modeling of the most dangerous (critical) flight modes and modeling of actual accidents.

Modern training of crews should be multistage, and according to the regulations, most of flight training programs should cover simulator training provided for appropriate technical development.

2. Components of professional readiness of student pilots for performance of fighting tasks are analyzed.

The model of process of formation of professional readiness of cadet pilots for performance of fighting tasks is based on the following components: motivational, orientation, operational, strong-willed, estimating.

3. Components and components of structure of readiness of future pilots for performance of fighting tasks are analyzed.

Requirements to levels of formation of competence of future pilots as the professional readiness for performance of fighting tasks making them, the purpose and problems of formation, methodological approaches and the principles which are been the basis for the development of a technique of formation of readiness which has caused definition of pedagogical conditions, providing effective realization of the modeled pedagogical process are reflected in model.

4. The main maintenance of a process model of formation of professional readiness of future pilots which is implemented in the course of training preparation is formulated.

In a competence-based component of structure of readiness of future pilots we select such index as professional knowledge and skills of execution of fighting tasks (execution of different types of fighting flights). Content of psychology and pedagogical knowledge is defined by training programs of training of pilots. The psychology and pedagogical readiness consists of knowledge of methodological bases and categories of flight business; regularities of socialization and development of the personality: entities, purposes and technologies of training and education; are a basis of 
creative thinking of the pilot. The ability - is a set of serial torn actions based on theoretical knowledge. A part of these actions can be automated (skills). Motivational and reflexive component. The reflexive component is characterizing knowledge and the analysis by the pilot of the phenomena of own consciousness and activities. This component through such reflexive processes as self-understanding and understanding of another, a self-assessment and assessment of others and so forth is implemented. Motivation - the positive relation to flight activities, desire to be engaged in it. The motivation of the identity of a pilot is caused by his professional interests, valuable orientations, ideals. It is shown both in all his professional activity, and in separate fighting situations, defines its perception of external events and logic of behavior in runtime of fighting tasks. A personal component - that is set of the personal qualities important for execution of fighting tasks. Creativity of a pilot is implemented in the original decision of fighting tasks, in the process optimization of execution of fighting tasks.

\section{References}

[1] Gander, D. V. (2007). Professional psychopedagogy. Moscow: Voentehizdat, 336.

[2] Sahati, T. (1993). Making decisions. The method of hierarchy analysis. Moscow: Radio and communication, 214.

[3] Kremeshnyi, A. I., Pryimak, A. B. (2002). Simulator complexes for aviation - real need. Design and production of plane structures, 31 (4), 23-29.

[4] Voloshin, V. V. (2002). Flight safety starts with ground preparation. Journal of Aviation and Astronautics, 3, 34-35.

[5] Bruce, D. (2001). Nordwall. Technology Ushers in a Revolution Simulation. Aviation Week \& Space Technology, 450-452.

[6] Bunker, M. (1989). Evolution of GE CIG Systems, SCSD Document. Daytona Beach: General Electric Company, 684.

[7] Chorna, I. M. (2003). Formation of psychological readiness of future teachers for professional work at schools. Ternopil, 349 .

[8] Makarov, R. N., Zaretskyi, V. M., Kodola, V. H. (2003). Human factor; aviation, flight learning, simulators. Moscow: MAPCHAK, 524.

[9] Kazachkyn, B. I., Nemchykov, G. A., Kobelkov, I. A., Kodola, V. G. (1999). Aircraft simulators as a linking chainin ground-to-air preparation. Monino, 160.

[10] Epihina, N. A. (2009). Methodology of simulator training of pilots during break between flights. Kharkiv, 18.

[11] Rules of certification of flight simulators (2002). Mintrans Ukrainy, No. 529. Available at: http:// zakon1.rada.gov.ua/laws/show/z0687-02

[12] Makarov, R. N., Nedelko, S. N., Bamburkyn, A. P., Grygoretskyi, V. A. (2005). Aviation pedagogy. Moscow-Kirovograd: MNAPCHAK-GLAU, 433.

[13] Apenko, N. V. (2012). State and prospects of aircraft flight simulators building. Proceedings of National Aviation University, 52 (3), 78-81. doi: 10.18372/2306-1472.52.2353

[14] Zaitsev, V. (2005). Using simulators during preparation of US Navy pilots. Zarubezhnoe voennoe obozrenie, 2, 59-64.

[15] Ivanov, V. L., Ruhayn, A. B., Cheked, I. V. (2004). Aviation equipment of military aircrafts. Part I. Oxygen equipment and protection of military aircrafts. Technical meanss of aerial reconnaissance. Kyiv: NAU Publisher, 232.

[16] Bodner, V. A., Zakyrov, P. A., Smirnova, I. M. (1978). Aircraft trainers. Moscow: Mashinostroenie, 192.

[17] Kharchenko, V. P., Lazorenko, V. A. (2007). Principles for improving modular simulators for practical training of air traffic controllers. Proceedings of National Aviation University, 33 (3-4), 3-8. doi: 10.18372/2306-1472.33.1487

[18] Tsvyrkun, A. D. (1975). Structure of complex systems. Moscow: Sovetskoe radio, 196.

[19] Sokhan, L. B., Ermakova, I. G., Nesen, G. M. (Eds.) (2003). Life competence. Kyiv: Bogdana, 520.

[20] Vorona, A. A., Gander, D. V., Ponomarenko, V. A. (2000). Psychological and pedagogical principles of professional preparation of crews. Moscow: MAKCHAK, 340. 